Clarke, P. H. \& Cowan, S. T. (1952). J. gen. Microbiol. 6, 187-197

\title{
Biochemical Methods for Bacteriology
}

\author{
By PATRICIA H. CLARKE and S. T. COWAN \\ National Collection of Type Cultures, Colindale Avenue, London, N.W. 9
}

\begin{abstract}
SUMMARY: A series of biochemical methods using heavy suspensions of organisms and chemically-defined solutions are described; they include fermentations, reduction of nitrate and of methylene blue, production of indole, hydrogen sulphide and acetoin, and hydrolysis of gelatin, starch and urea. The tests use the preformed enzymes of the bacterial cells and the results are not complicated by side effects or the multiple reactions that occur in cultures growing in a nutrient medium containing the test substrate.
\end{abstract}

Methods developed by biochemists are seldom used in the characterization of bacterial species. Bacteriologists' tests are normally made in undefined media and the end-result often is a balance of opposing reactions; this applies particularly to the fermentation tests in which acid production from the breakdown of 'sugar' must exceed alkali produced from the breakdown of protein constituents. Davis (1939) added washed bacterial suspensions to powdered sugars and showed that these non-multiplying suspensions gave clearer acid production than the same organisms growing in a nutrient medium containing the sugar. We applied the principle of testing for preformed enzymes in washed suspensions to other biochemical tests and, to avoid the need for massive growths, developed methods using small volumes of reagents.

Micromethods have recently gained favour with bacteriologists (Arnold \& Weaver, 1948; Cook, 1948; Elek, 1948; Hannan \& Weaver, 1948; Brough, 1950; Galton, Hardy \& Mitchell, 1950; Morse \& Weaver, 1950; Bachmann \& Weaver, 1951; Fabrizio \& Weaver, 1951; Hargrove \& Weaver, 1951), but nearly all depend on a heavy inoculum and the growth of the organisms in a small volume of medium containing the test substrate. In the development of our methods speed has not been the determining factor, but a reasonably quick result has advantages in that a sterile technique is unnecessary. Chemically clean glassware is essential.

\section{METHODS}

\section{Suspensions}

Bacteria were grown on a favourable solid medium, preferably without blood or fermentable substance. Incubation was at the optimal temperature and for the shortest time (usually 18-24 hr.) to produce a good growth. A suspension was made by washing the growth from the slope or plate in tap water; this was spun to deposit the cells, and the deposit resuspended in a small volume of water. Suspensions made from blood agar cultures were washed once to remove haemoglobin. For a series of 20 'capillary sugars' and the full range of biochemical tests to be described, 1-1.5 ml. of heavy suspension was required. The number of slopes or plates of each culture incubated depended 
on the amount of harvested cells to be expected and the number of tests to be made. Nutrient agar slopes, $100 \mathrm{~mm}$. long in $150 \times 20 \mathrm{~mm}$. tubes, were used for most organisms; 1-2 slopes of vigorously growing bacteria such as coliforms, pseudomonads and staphylococci normally provided ample growth, but 3-10 slopes or 1-4 plates of serum or blood agar were needed for organisms such as Streptococcus pyogenes, Clostridium tetani and Corynebacterium hofmannii.

\section{Effect of suspension concentration and age of cultures}

Suspensions were made as dense as the growth would allow, but there was a minimum opacity equivalent to a total count of $c .1 \times 10^{11}$ cells $/ \mathrm{ml}$. below which the reactions became slower, weaker or uncertain. Dilution of the suspension and the age of the culture used in its preparation affect the speed and intensity of reactions. This is illustrated by the results obtained with Pseudomonas hydrophila (Table 1). Viable counts (Miles \& Misra, 1938) on $P s$. hydrophila suspensions showed that $10^{8}$ organisms $/ \mathrm{ml}$. were inactive; from

Table 1. Effect of (a) age of culture and (b) suspension concentration on glucose fermentation and biochemical tests shown by Ps. hydrophila (NCTC 7810)

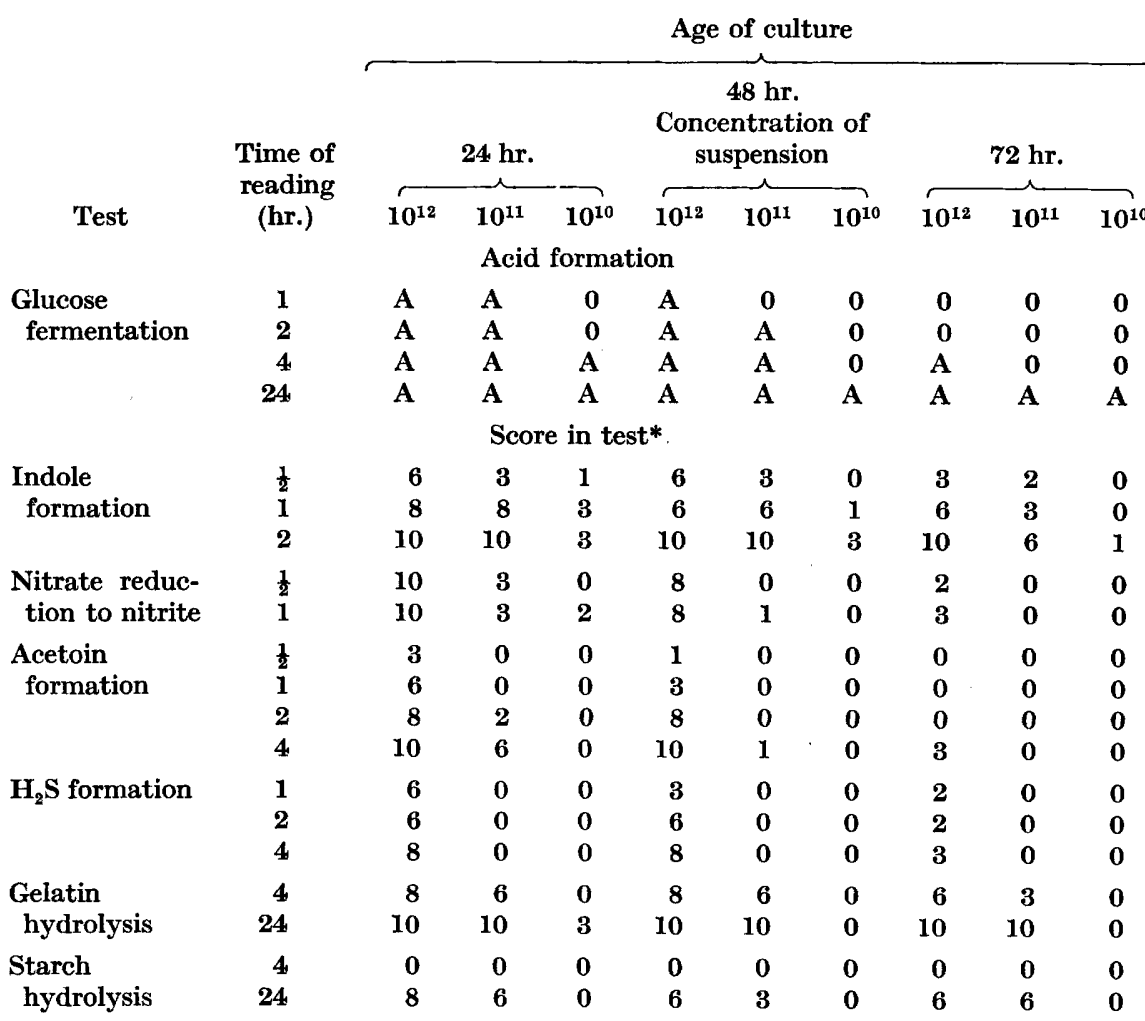

$A=$ acid formed.

* Numbers represent relative strength of reaction: $10=$ maximum; $3=$ definite positive; 2 and $1=$ trace reactions. $0=$ no reaction. 
this it is clear that unsterilized glassware and tap water are not likely to introduce false reactions.

Effect of medium. The medium on which the culture is grown is important only if it encourages the development of an adaptive enzyme or if it inhibits the production of certain enzymes. A strain of Bacterium dispar took 8 days to ferment $1 \%$ lactose in peptone water; suspensions made from growth on nutrient agar took $48 \mathrm{hr}$. to ferment $5 \%$ lactose in our microtest, but suspensions made from lactose agar fermented lactose in $24 \mathrm{hr}$. The effect of growth on glucose agar will be considered in connexion with the tests for acetoin and indole.

$B$ uffer is desirable to prolong enzyme action but excess will slow the reactions; $0.025 \mathrm{M}$-phosphate buffer was found to be the optimal concentration for those tests in which this effect was studied.

Volumes were measured with dropping pipettes (Donald, 1913) but are only approximate as allowance was not made for the variation in drop-size of different solutions.

\section{FERMENTATIONS}

Three methods were tried and each showed that most bacteria have greater fermentative ability than is shown by the usual cultural tests in nutrient sugar media. Unfortunately, the three ways of testing our suspensions for preformed fermentative enzymes do not give identical results. Each method gives consistent results but only an extended trial and further experimental work will show which gives the best indication of the enzymic capacity of the test organism.

'Sugar' solutions. Glucose, xylose, lactose, sucrose, maltose and glycerol were made up as $25 \%$ (w/v) solutions. Sugars with lower solubilities were made up as follows: galactose, $20 \%$; raffinose, $10 \%$; starch, dextrin, mannitol, dulcitol and salicin, $5 \%$.

Buffer-indicator solution (BI). To $20 \mathrm{ml}$. 0.025 M-phosphate buffer (pH 6.8) was added $1.0 \mathrm{ml} .1 \%$ ethanolic bromcresol purple. Both sugar solutions and buffer-indicator solutions were sterilized by momentary autoclaving (Davis \& Rogers, 1939) or filtration.

Sugar-buffer-indicator solutions (SBI). Equal volumes of sugar solution and buffer-indicator solution were mixed in $65 \times 10 \mathrm{~mm}$. tubes. Mixtures were made up each week and when not in use were stored at $4^{\circ}$.

Method 1. Suspension (0.2 ml.), sugar solution (0.1 ml.), and BI (0.2 ml.) are mixed in $65 \times 10 \mathrm{~mm}$. tubes, and acid production observed after varying times in a $37^{\circ}$ water-bath.

Method 2. Suspension and SBI are mixed in approximately equal volumes in a capillary tube $10 \mathrm{~cm}$. long; one end of the capillary is sealed and the other stuck in plasticine. Readings are made at intervals after incubation at $37^{\circ}$.

Method 3. Durham's tubes $(35 \times 8 \mathrm{~mm}$.) are half-filled with $1 \%$ New Zealand agar $+0 \cdot 1 \%$ bromcresol purple. These columns are stored at $4^{\circ}$ until used. Two drops $(0.04 \mathrm{ml}$.) sugar solution are pipetted on to the surface of each column, and $0.02 \mathrm{ml}$. suspension added. Columns are incubated at $37^{\circ}$ and read up to $24 \mathrm{hr}$. 


\section{CAPILLARY TESTS}

The next three tests were made in capillary tubes $10 \mathrm{~cm}$. long. The tests are simple to carry out and to read, and comment seems unnecessary.

\section{Catalase}

'Ten vol.' $\mathrm{H}_{2} \mathrm{O}_{2}$ is run into a capillary tube, followed by suspension. Gas is usually evolved immediately and only tubes not showing gas within 10 sec. are sealed for longer observation.

\section{Methylene-blue reduction}

Standardized methylene blue (British Drug Houses Ltd.) in concentrations of 0.1 and $0.01 \%$ are mixed with suspension and sealed. Readings are made after 4 and $24 \mathrm{hr}$. at $37^{\circ}$.

\section{Urease}

Equal volumes of urea-buffer solution (urea $1 \%, 0.0125 \mathrm{~m}$ buffer $\mathrm{pH} \mathrm{6.0,}$ phenol red $\mathbf{0 . 0 0 0 2 5} \%$ ) and suspension are mixed. Sealed capillary tubes are incubated at $37^{\circ}$ and read for alkali production after 4 and $24 \mathrm{hr}$.

\section{TESTS ON AGAR COLUMNS}

\section{Gelatin hydrolysis}

To detect gelatin hydrolysis Frazier (1926) flooded nutrient gelatin with acid mercuric chloride; this formed a thick white opalescence with the gelatin and left clear zones in areas of hydrolysis. Oakley, Warrack \& Warren (1948) adapted the method to estimate gelatinases in bacterial toxins, using columns of $0.4 \%$ gelatin and $1 \%$ agar in water. For our microtest the columns were made up with $0.4 \%$ gelatin and $0.5 \%$ New Zealand agar. We found $0.5 \%$ agar gave rather better results than $1 \%$; when the gelatin concentration was less than $0.4 \%$ the opacity of the control tube was too faint. No difference was observed in the results for organisms grown on nutrient agar, serum agar, or $1 \%$ glucose agar. The mercuric chloride diffuses slowly through the agar, and tests should be left on the bench for at least $30 \mathrm{~min}$. before reading. The tubes were read against a blank gelatin-agar tube, and a positive reaction was indicated by a clear zone under the meniscus. (For a fuller description of the appearance of the tube, see Oakley et al. 1948.)

Cl. botulinum, Cl. histolyticum, Cl. sporogenes, Cl. welchii, Ps. hydrophila, Staphylococcus aureus and Vibrio spp. gave positive results at either 4 or $24 \mathrm{hr}$.; no positive reactions were obtained from organisms negative by the cultural method.

Method. Suspension is prepared from a $24 \mathrm{hr}$. culture grown on any suitable medium. For each test $0.04 \mathrm{ml}$. suspension is pipetted into each of two Durham's tubes containing $\mathbf{0} \cdot 4 \mathrm{ml}$. gelatin-agar base. The tubes are placed in the air incubator at $37^{\circ}$ and one is tested at 4, and the other at $24 \mathrm{hr}$. Acid mercuric chloride $\left(\mathrm{HgCl}_{2}, 15 \mathrm{~g}\right.$.; distilled water, $100 \mathrm{ml}$.; conc. $\mathrm{HCl}, 20 \mathrm{ml}$.) is added, and the tubes read after $\mathbf{3 0} \mathrm{min}$. at room temperature against a blank gelatin-agar tube treated in the same way. 


\section{Starch hydrolysis}

The microtest for starch hydrolysis is based on the same principle as that for gelatin. The suspension is placed on a column of starch-agar and, at the end of the test period, Lugol's iodine is added to test for the remaining starch. The optimum composition of the column was found to be $0.2 \%$ agar and $0.05 \%$ potato starch.

Positive reactions were obtained in $2 \mathrm{hr}$. with the more active starchhydrolysing organisms, but we decided to use 4 and $24 \mathrm{hr}$. as the test periods, so that the weaker reactors could be detected. Positive results were obtained with Cl. sporogenes, Ps. hydrophila, Shigella dysenteriae, Sh. flexneri and Vibrio spp.

Method. Suspension is prepared from a $24 \mathrm{hr}$. culture grown on any suitable medium. For each test $0.04 \mathrm{ml}$. suspension is pipetted into each of two Durham's tubes containing $\mathbf{0 . 4} \mathbf{~ m l}$. starch-agar base. The tubes are placed in the air incubator at $37^{\circ}$ and tested at 4 and $24 \mathrm{hr}$. Lugol's iodine $(2 \%$ potassium iodide, $1 \%$ iodine, in distilled water) is added and the tubes read after $30 \mathrm{~min}$. at room temperature against a blank starch-agar tube treated in the same way.

\section{Hydrogen sulphide}

The production of $\mathrm{H}_{2} \mathrm{~S}$ from peptone media depends on the reduction of sulphur from sulphur-containing amino-acids or other sulphur compounds in the medium. We devised a micromethod for the detection of $\mathrm{H}_{2} \mathrm{~S}$-production from cystine. Morse \& Weaver (1950), in their microtest using 'thiopeptone', obtained satisfactory results with lead acetate paper. In the small volumes with which we were working the amounts of $\mathrm{H}_{2} \mathrm{~S}$ formed were insufficient to be detected by this method. We attempted to carry out the test with a strand of cotton impregnated with lead acetate inserted at the top of a capillary tube, but this was not sensitive enough. Finally we made the test at the top of a column of lead acetate agar, where the $\mathbf{H}_{2} \mathrm{~S}$ formed was detected by the development of a brown or black colour at the interface. The lead acetate agar base (LAAB) was prepared by adding $1 \mathrm{ml}$. of a $0.05 \%$ solution of basic lead acetate (to which just enough $\mathrm{HCl}$ had been added to prevent precipitation) to $9 \mathrm{ml} .1 \%$ New Zealand agar in water. LAAB was more sensitive than ferric ammonium citrate agar. The cystine was made up in $0 \cdot 1 \mathrm{~N}-\mathrm{HCl}$ and ad-

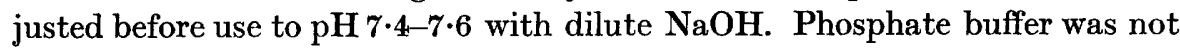
used as it did not improve the sensitivity and, by reacting with the lead acetate, made the test more difficult to read. The addition of sodium thiosulphate had no effect on the speed or intensity of the reaction. The optimum $\mathrm{pH}$ was not critical; $P$ s. hydrophila gave positive reactions at $\mathrm{pH}$ values $6 \cdot \mathbf{0}, \mathbf{6} \cdot \mathbf{4}, \mathbf{6} \cdot \mathbf{8}, \mathbf{7 \cdot 2}$, $7 \cdot 6,7 \cdot 8$ and 8 , but the reactions were stronger and more rapid at $\mathrm{pH} 7 \cdot 2-7 \cdot 8$.

With a heavy suspension of an $\mathrm{H}_{2} \mathrm{~S}$-positive organism a black ring develops in 15-30 min. With most organisms the strength of the reaction and the rate at which it is produced depend on the concentration of the suspension. A $10^{12}$ organisms/ml. suspension of a $24 \mathrm{hr}$. culture of Ps. hydrophila produced a strong reaction in $30 \mathrm{~min}$., but $10^{10}$ organisms $/ \mathrm{ml}$. gave no reaction in $24 \mathrm{hr}$. 
Heavy suspensions of most of the organisms we tested gave positive results in 1-2 hr., but we left the tubes overnight so that weak reactions could be observed. This method is rather more sensitive than the cultural method for the detection of $\mathbf{H}_{2} \mathrm{~S}$ from peptone water. Positive results were obtained with Bact. aerogenes, Bact. coli, Cl. histolyticum, Cl. sporogenes, Proteus morganii, Ps. hydrophila and Salmonella typhi.

Method. Suspension is prepared from a $24 \mathrm{hr}$. culture grown on any suitable medium. To columns of $0.4 \mathrm{ml}$. LAAB in Durham's tubes are added $0.04 \mathrm{ml}$. cystine solution $(0.1 \%$ at $\mathrm{pH} 7 \cdot 4)$ and $0.04 \mathrm{ml}$. suspension. The tubes are placed in the air incubator at $37^{\circ}$ and read at intervals up to $24 \mathrm{hr}$.

\section{OTHER TESTS}

\section{Nitrate reduction}

The reduction of nitrate to nitrite was detected with dimethyl- $\alpha$-naphthylamine (Wallace \& Neave, 1927) and sulphanilic acid. The reaction was rapid with all the species tested; at $30 \mathrm{~min}$. the results were consistent with the usual cultural method. We did not have any false negatives produced by reduction of nitrite, but these could be detected by zinc dust (ZoBell, 1932).

Method. Suspension, $0.04 \mathrm{ml}$., is mixed in $65 \times 10 \mathrm{~mm}$. tubes with $0.05 \%$ $\mathrm{NaNO}_{3}, 0.06 \mathrm{ml}$; ; phosphate buffer (0.025 M, pH 6.8), 0.04 ml. After $30 \mathrm{~min}$. at $37^{\circ}$ (water-bath) $0.06 \mathrm{ml}$. dimethyl- $\alpha$-naphthylamine solution $(6 \mathrm{ml} . / \mathrm{l}$. $5 \mathrm{~N}$-acetic acid) and $0.06 \mathrm{ml}$. sulphanilic acid (8 g. $/ 1.5 \mathrm{~N}$-acetic acid) is added and read 5 min. later. A blank test on the nitrate and buffer is included with each batch of tests.

\section{Acetylmethylcarbinol (acetoin)}

Acetoin is formed from the breakdown of glucose by Bact. aerogenes and other bacterial species. Harden (1906) showed that it was the active substance in the Voges-Proskauer test; on the addition of strong potassium hydroxide the acetoin is oxidized to diacetyl which then condenses with substances in the medium containing a guanidine group to give a red colour. Acetoin can also be detected and estimated by oxidation to diacetyl and precipitation as the red nickel dimethylglyoxime (Lemoigne, 1920; Kluyver, Donker \& Visser't Hooft, 1925), and estimated by iodine titration (Langlykke \& Peterson, 1937). As the V.P. reaction is very sensitive and could easily be adapted to the microtechnique, we preferred a method derived from it. Glucose, creatine, and $0.025 \mathrm{M}$-phosphate buffer ( $\mathrm{pH} \mathrm{6.8)}$ were used as the substrate; glucose at $10 \%$ gave better results than 5 or $25 \%$. Creatine gave better results than $5 \%$ peptone, arginine, or guanidine nitrate, and there was no significant difference between adding creatine with the glucose or adding it with the test reagents, $5 \%$ ethanolic $\alpha$-naphthol (Barritt, 1936) and $40 \% \mathrm{KOH}$.

Medium and $\mathrm{pH}$ value. Suspensions of Ps. hydrophila from cultures grown $24 \mathrm{hr}$. on nutrient agar at $\mathrm{pH} 7 \cdot 6$ gave strong reactions after $1-2 \mathrm{hr}$. at $37^{\circ}$ (water-bath), although Bact. coli and Bact. aerogenes were negative. After $24 \mathrm{hr}$. traces of acetoin could be detected with both Bact. coli and Bact. aerogenes suspensions. Strong reactions with Bact. aerogenes suspensions from 
nutrient agar were only obtained after $24 \mathrm{hr}$. in the presence of peptone, which may have allowed growth to take place. Suspensions of Bact. aerogenes from cultures grown $24 \mathrm{hr}$. on $1 \%$ glucose agar or acid agar (nutrient agar at $\mathrm{pH} 4$ ) gave strong reactions in $\mathbf{3 0}$ min., while Bact. coli suspensions from glucose or acid agar behaved as those from nutrient agar (Table 2). Ps. hydrophila, tested after 30 min., gave stronger reactions when grown on glucose agar (Table 2).

Table 2. Acetoin production by suspensions from growth on different media

Glucose $10 \%, 0.02 \mathrm{ml}$; creatine $0.2 \%, 0.02 \mathrm{ml}$.; buffer 0.04 $\mathrm{ml}$.; suspension, $0.04 \mathrm{ml}$.

Suspension of culture

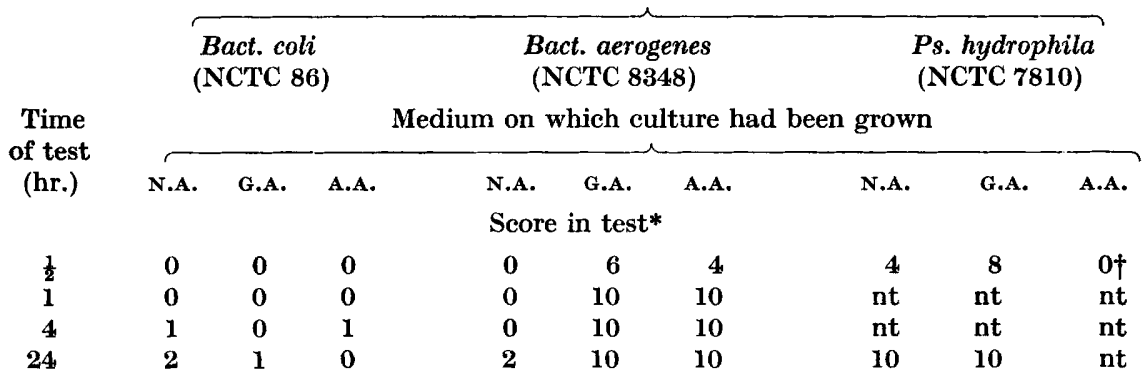

N.A. = nutrient agar; G.A. = glucose agar; A.A. = acid agar.

* Numbers 0 to 10 represent relative scoring of strength of reaction; see Table 1 . $\dagger=$ no visible growth on acid agar; $\mathrm{nt}=$ not tested.

Silverman \& Werkman (1941) showed that the Bact.aerogenes enzyme system responsible for acetoin production from pyruvic acid was only formed when the organism was grown on an acid medium, and that crude enzyme expressed from the bacteria had a $\mathrm{pH}$ optimum of about $\mathrm{pH} 5$.

A pH curve (Sørensen's phosphate buffers 0.025 $\mathrm{m}$ or 0.06 M, pH 4.5-8.0) with suspensions of Bact. aerogenes and Ps. hydrophila grown on glucose agar, showed an optimum on the acid side of the range. After $2 \mathrm{hr}$. the breakdown of glucose had produced enough acid to overcome the effect of the $0.06 \mathrm{M}$ buffer, and there was little difference in the results obtained in tubes with initial $\mathrm{pH}$ values between $\mathbf{4 . 5}$ and $\mathbf{7 \cdot 2}$ (Table 3 ). We did not attempt to determine the $\mathrm{pH}$ optimum more accurately. For the microtests the greatest sensitivity was obtained by starting the reaction at a $\mathrm{pH}$ slightly higher than the optimum, and using a weak buffer. With no buffer, or if the reaction was started at a lower $\mathrm{pH}$, the system became too acid. We therefore started our tests at pH 6.8 with $0 \cdot 025$ m buffer.

Time. The optimum incubation period depends on the sensitivity required. At $24 \mathrm{hr}$. the test is more sensitive than the usual cultural methods, and Bact. coli suspensions are weakly positive. Again, after the reagents are added and the tubes shaken to aerate the solutions, the rate at which the colour develops depends on the amount of acetoin present. With very small quantities the colour development may be delayed for 1-2 hr. For the detection of minimal quantities the suspension-glucose mixture should be left at $37^{\circ}$ for $24 \mathrm{hr}$. and the test read up to $1 \mathrm{hr}$. after the reagents have been added. For routine use 
Table 3. Effect of $\mathrm{pH}$ value and buffer concentration on acetoin production by:

(P) Ps. hydrophila NCTC 7810 and by (B) Bact. aerogenes NCTC 8348

Glucose $10 \%, 0.02 \mathrm{ml}$; ; creatine 0.2 \%, 0.02 ml.; buffer 0.04 ml.; suspension 0.04 ml.

\begin{tabular}{|c|c|c|c|c|c|c|c|c|c|c|c|c|c|c|c|c|c|}
\hline \multirow[b]{2}{*}{ Organism } & \multirow{2}{*}{$\begin{array}{l}\text { Time } \\
\text { of test } \\
\text { (min.) }\end{array}$} & \multicolumn{8}{|c|}{$\begin{array}{l}0.025 \mathrm{M} \text { phosphate buffer } \\
\text { initial } \mathrm{pH} \text { value } \dagger\end{array}$} & \multicolumn{8}{|c|}{$\begin{array}{l}\text { 0.06 m phosphate buffer } \\
\text { initial } \mathrm{pH} \text { value } \dagger\end{array}$} \\
\hline & & 4.5 & $5 \cdot 6$ & $6 \cdot 0$ & $6 \cdot 4$ & $6 \cdot 8$ & $7 \cdot 2$ & $7 \cdot 6$ & 8.0 & 4.5 & $5 \cdot 6$ & $6 \cdot 0$ & $6 \cdot 4$ & $6 \cdot 8$ & $7 \cdot 2$ & $7 \cdot 6$ & 8.0 \\
\hline & & \multicolumn{16}{|c|}{ Score in test* } \\
\hline \multirow[t]{5}{*}{$\mathbf{P}$} & 5 & 3 & 2 & 2 & 2 & 1 & 1 & 0 & 0 & 3 & 3 & 1 & 1 & 1 & 1 & 1 & 1 \\
\hline & 15 & 6 & 6 & 4 & 6 & 5 & 2 & 3 & 4 & 4 & 4 & 4 & $\mathbf{3}$ & 3 & 2 & 2 & 2 \\
\hline & 30 & 8 & 8 & 8 & 8 & 8 & 8 & 7 & 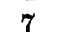 & 6 & 6 & 6 & 6 & 6 & 4 & $\mathbf{3}$ & 3 \\
\hline & 60 & 10 & 10 & 10 & 10 & 10 & 10 & 10 & 10 & 8 & 8 & 10 & 10 & 10 & 10 & 10 & 10 \\
\hline & 120 & 10 & 10 & 10 & 10 & 10 & 10 & 10 & 10 & 10 & 10 & 10 & 10 & 10 & 10 & 10 & 10 \\
\hline \multirow[t]{5}{*}{ B } & 5 & 2 & 1 & 1 & 1 & 1 & 1 & 1 & 1 & 1 & 1 & 1 & 1 & 2 & $\mathbf{1}$ & 1 & $\mathbf{0}$ \\
\hline & 15 & 4 & 4 & 4 & 3 & 2 & 2 & 1 & 1 & 2 & 2 & 1 & 0 & 1 & 0 & 0 & 0 \\
\hline & 30 & 6 & 6 & 8 & 8 & 7 & 6 & 6 & 6 & 3 & 3 & 3 & 3 & 1 & 1 & 1 & 1 \\
\hline & 60 & 8 & 8 & 9 & 9 & 9 & 9 & 9 & 9 & 6 & 6 & 6 & 6 & 3 & 2 & $\mathbf{1}$ & 1 \\
\hline & 120 & 10 & 10 & 10 & 10 & 10 & 10 & 10 & 10 & 7 & 8 & 8 & 9 & 9 & 10 & 5 & 4 \\
\hline
\end{tabular}

* Numbers 0-10 represent relative scoring of strength of reaction; see Table 1 .

$\dagger$ Initial pH value; fermentation products cause a decrease in $\mathbf{p H}$ value during the experiment.

we adopted an incubation period of $1 \mathrm{hr}$. and read the tests $10 \mathrm{~min}$. after the addition of the reagents. Under these conditions the test clearly distinguished between Bact. coli and Bact. aerogenes grown on glucose agar.

Method. Suspension is prepared from a $24 \mathrm{hr}$. culture grown on $1 \%$ glucose agar, and $0.04 \mathrm{ml}$. suspension is added to a mixture of $10 \%$ glucose, $0.02 \mathrm{ml}$; $0.2 \%$ creatine, $0.02 \mathrm{ml}$; $0.025 \mathrm{M}$-phosphate buffer (pH 6.8), $0.04 \mathrm{ml}$; in a $65 \times 10 \mathrm{~mm}$. tube. After incubation in a water-bath at $37^{\circ}$ for $1 \mathrm{hr} ., 0.06 \mathrm{ml}$. $5 \%$ ethanolic $\alpha$-naphthol is added and the tubes shaken; $0.04 \mathrm{ml} .40 \% \mathrm{KOH}$ is then added, the tubes shaken again, returned to the water-bath for $10 \mathrm{~min}$., shaken again and read.

\section{Indole}

The production of indole from peptone depends on the presence of tryptophan in the medium. When the suspension from a culture grown on nutrient agar is incubated with tryptophan, indole is formed fairly rapidly and can be detected by any of the indole test reagents. Kovac's reagent was preferred to Böhme's as the results were easier to read and only one solution was needed. Kovac's reagent was made up in pure isoamyl alcohol, which Arnold \& Weaver (1948) found gave better results than the other alcohols tested. In a dark bottle the solution remained stable on the bench for several months; the colour remained a golden yellow and no false colorations appeared in the test.

Tryptophanase is only formed when the organism is grown in the presence of tryptophan and in the absence of glucose. Evans, Handley \& Happold (1941) showed that non-viable suspensions of cultures grown with glucose or on tryptophan-free medium would develop tryptophanase when left in contact with tryptophan for a short time. 
In the microtest for indole, indole-positive organisms were grown on nutrient or serum agar and suspensions gave positive results in $\frac{1}{2}-1 \mathrm{hr}$. Bact. coli and Bact. aerogenes were grown on glucose agar for the acetoin test, and these suspensions were used to check the effect of growth on glucose on the other microtests. Only the indole reaction was affected and, as Evans et al. (1941) found, the inhibition of the tryptophanase activity by Bact. coli was overcome after the suspension had been in the presence of tryptophan for 1-3 hr. ('Table 4). Similar results were obtained with $P$ s. hydrophila and $\boldsymbol{P r}$. morganii. It is, therefore, possible to carry out all the microtests on suspensions from glucose agar cultures if the duration of the indole test is prolonged.

Table 4. Indole production by suspensions from growth on agar and glucose agar Tryptophan 0.1 \%, $0.06 \mathrm{ml}$; buffer, 0.04 ml.; suspension, 0.04 ml.

\begin{tabular}{|c|c|c|c|c|}
\hline \multirow{4}{*}{$\begin{array}{c}\text { Time } \\
\text { of test } \\
\text { (hr.) }\end{array}$} & \multicolumn{4}{|c|}{ Suspension of culture } \\
\hline & \multicolumn{2}{|c|}{$\begin{array}{c}\text { Bact. coli } \\
\text { (NCTC 86) }\end{array}$} & \multicolumn{2}{|c|}{$\begin{array}{l}\text { Bact. aerogenes } \\
\text { (NCTC 8348) }\end{array}$} \\
\hline & \multicolumn{4}{|c|}{ Medium on which culture had been grown } \\
\hline & N.A. & G.A. & N.A. & G.A. \\
\hline & \multicolumn{4}{|c|}{ Score in test* } \\
\hline $0 \cdot 5$ & 6 & $\mathbf{0}$ & $\mathbf{0}$ & $\mathbf{0}$ \\
\hline 1 & 8 & 1 & 0 & 0 \\
\hline $1 \cdot 5$ & 8 & 3 & $\mathbf{0}$ & $\mathbf{0}$ \\
\hline 2 & 10 & 6 & $\mathbf{0}$ & $\mathbf{0}$ \\
\hline 3 & 10 & 10 & $\mathbf{0}$ & $\mathbf{0}$ \\
\hline 4 & 10 & 10 & $\mathbf{0}$ & $\mathbf{0}$ \\
\hline
\end{tabular}

N.A. = nutrient agar; G.A. = glucose agar.

* Numbers 0-10 represent relative scoring of strength of reaction; see Table 1.

For very light suspensions and when older cultures are used, an incubation period of 4-6 hr. for the test may be necessary, but for our usual test we have taken an incubation period of $1 \mathrm{hr}$. when the organism is grown on nutrient or serum agar and 2-3 hr. when grown on glucose agar. Among the limited number of organisms tested no positive reactions were obtained for cultures negative by the cultural methods. Bact. coli, Cl. bifermentans, Ps. hydrophila, Pr. morganii gave positive results.

Method. Suspension is prepared from a culture grown on nutrient agar, serum agar, or $1 \%$ glucose agar, and $0.04 \mathrm{ml}$. is added to a mixture of $0.1 \%$ DL-tryptophan, $0.06 \mathrm{ml}$. and $0.025 \mathrm{M}$-phosphate buffer (pH 6.8), 0.04 ml. The tubes are incubated in the water-bath at $37^{\circ}$ for $1 \mathrm{hr}$. $(3 \mathrm{hr}$. when suspension is from a glucose medium) and $0.06 \mathrm{ml}$. Kovac's reagent ( $p$-dimethylaminobenzaldehyde, $5 \mathrm{~g}$.; isoamyl alcohol, $75 \mathrm{ml}$.; conc. HCl, $25 \mathrm{ml}$.) added. The tubes are shaken and read immediately.

\section{DISCUSSION}

The advantages of the methods described in this paper are simplicity of technique, clear-cut results, use of chemically-defined substrates instead of complex media, small amount of cells required to carry out a series of tests, rapidity and reproducibility. We have approached the bacterial cell as 
a system of preformed enzymes, and, using viable but non-multiplying suspensions, we tried to devise tests for the enzyme reactions used in bacterial characterization. With this in mind it is necessary to consider whether we want to assess the actual or the potential enzymic capacity of the cell. On nutrient agar at $\mathrm{pH} \mathrm{7.6} \mathrm{Bact.} \mathrm{aerogenes} \mathrm{does} \mathrm{not} \mathrm{form} \mathrm{the} \mathrm{acetoin-producing} \mathrm{enzyme,}$ but it can be seen as a potential enzyme system because it is formed when the

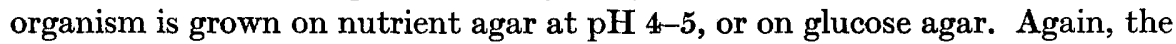
tryptophanase of Bact. coli, developed on nutrient agar, is inhibited when the organism is grown on a glucose medium. In this system the tryptophanase becomes active when the cells are in contact with tryptophan for about an hour. Therefore, if we want to realize the potentialities of the enzyme pattern, we may need to vary the conditions of our tests and to modify the medium on which the organism is grown. On the other hand, the ability to produce an enzyme on a particular medium may be of value in differentiating taxonomic groups; for example, the production of the acetoin enzyme by $\boldsymbol{P s}$. hydrophila on nutrient agar distinguishes it from Bact. aerogenes.

When the sensitivity of a test is increased, some organisms previously described as negative may be shown to give weakly positive reactions; this may arise either from an increase in the sensitivity of the test reagents, or from a change in the conditions of test. In this study only the $\mathrm{H}_{2} \mathrm{~S}$, acetoin and fermentation tests gave greater sensitivity. For the $\mathbf{H}_{2} \mathrm{~S}$ test we devised a sensitive indicator, but with non-growing organisms, very heavy suspensions were needed. The detection of $\mathrm{H}_{2} \mathrm{~S}$ in culture media is made unsatisfactory by variation in media; in this laboratory we found that $0.1 \%$ cystine added to nutrient broth made each batch more consistently useful for $\mathbf{H}_{2} \mathrm{~S}$ production as detected by lead acetate papers (ZoBell \& Feltham, 1934), but our microtest, like that of Morse \& Weaver (1950), is even more sensitive.

Fabrizio \& Weaver (1951) showed that most coliforms are able to produce some acetoin; this can also be shown by using highly sensitive test reagents (Batty-Smith, 1941) on 10 to 14-day cultures in glucose phosphate peptone medium (unpublished observations). We may have to decide between detecting all the positive reactors up to the sensitivity limit of our tests or choosing conditions which will give consistency with the accepted cultural method.

So far these tests have been worked out and applied to only a limited number of strains. If experience shows that we cannot resolve the discrepancies between the tests on growing cultures and on washed suspensions we shall not be able to apply the microtests to ordinary diagnostic work. However, our methods show more clearly than growing cultures the fundamental enzymic make-up of bacteria, and may show unsuspected relationships between different species or genera. As a systematic study, a re-characterization of species on the basis of enzymic patterns may be just as important and profitable as antigenic analysis.

\section{REFERENCES}

Arnold, W. M., JUn. \& Weaver, R. H. (1948). Quick microtechniques for the identification of cultures. I. Indole production. J. Lab. clin. Med. 33, 1334.

Bachmann, B. \& Weaver, R. H. (1951). Rapid microtechnics for identification of cultures. V. Reduction of nitrates to nitrites. Amer. J. clin. Path. 21, 195. 
Barrit, M. M. (1936). The intensification of the Voges-Proskauer reaction by the addition of $\alpha$-naphthol. J. Path. Bact. 42, 441.

BatTy-Smith, C. G. (1941). The detection of acetyl-methyl-carbinol in bacterial cultures. A comparative study of the methods of O'Meara and of Barritt. J. Hyg., Camb. 41, 521.

Brough, F. K. (1950). A rapid microtechnique for the determination of nitrate reduction by micro-organisms. J. Bact. 60,365 .

Coox, G. T. (1948). Urease and other biochemical reactions of the Proteus group. J. Path. Bact. 60, 171.

Davis, J. G. (1939). A rapid, simple and reproducible method for the determination of bacterial sugar fermentations. Zbl. Bakt. (2 Abt.), 101, 97.

Davis, J. G. \& Rogers, H. J. (1939). The effect of sterilisation upon sugars. Z Zbl. Bakt. (2 Abt.) 101, 102.

Donald, R. (1913). An apparatus for liquid measurement by drops and applications in counting bacteria and other cells and in serology, etc. Proc. Roy. Soc. B, 86, 198.

Elek, S. D. (1948). Rapid identification of Proteus. J. Path. Bact. 60, 183.

Evans, W. C., Handiey, W. R. C. \& Happold, F. C. (1941). The tryptophanaseindole reaction. 4. Biochem. J. 35, 207.

Fabrizio, A. \& Weaver, R. H. (1951). Rapid microtechnics for identification of cultures. IV. Acetylmethylcarbinol production. Amer. J. clin. Path. 21, 192.

Frazier, W. C. (1926). A method for the detection of changes in gelatin due to bacteria. J. infect. Dis. 39, 302.

Galton, M. M., Hardy, A. V.\& MrtchelL, R. B. (1950). The public health laboratory diagnosis of enteric infections. Amer. J. trop. Med. 30, 77.

Hannan, J. \& Weaver, R. H. (1948). Quick microtechniques for the identification of cultures. II. Fermentations. J. Lab. clin. Med. 33, 1338.

Harden, A. (1906). On Voges and Proskauer's reaction for certain bacteria. Proc. Roy. Soc. B, 77, 424.

Hargrove, R. E. \& Weaver, R. H. (1951). Rapid microtechnics for identification of cultures. VI. Citrate utilization. Amer. J. clin. Path. 21, 286.

Kluyver, A. J., Donker, H. J. L. \& Visser'T HoofT, F. (1925). Über die Bildung von Acetylmethylcarbinol und 2, 3-Butylenglycol im Stoffwechsel der Hefe. Biochem. Z. 161, 361.

Langlykke, A. F. \& Peterson, W. H. (1937). The determination of acetylmethylcarbinol. Industr. Engng Chem. (Anal. ed.) 9, 163.

Lemorgne, M. (1920). Réaction spécifique du 2.3-butylèneglycol et de l'acétylméthylcarbinol, produits de la fermentation butylène glycolique. C.R. Acad. Sci., Paris, 170, 131.

Mrres, A. A. \& Misra, S. S. (1938). The estimation of the bactericidal power of the blood. J. Hyg., Camb. 38, 732.

Morse, M. L. \& Weaver, R. H. (1950). Rapid microtechnics for identification of cultures. III. Hydrogen sulfide production. Amer. J. clin. Path. $20,481$.

Oakrey, C. L., Warrack, G. H. \& Warren, M. E. (1948). The kappa and lambda antigens of Clostridium welchii. J. Path. Bact. 60, 495.

Silverman, M. \& Werkman, C. H. (1941). The formation of acetylmethylcarbinol from pyruvic acid by a bacterial enzyme preparation. J. biol. Chem. 138, 35 .

Wallace, G. I. \& Neave, S. L. (1927). The nitrite test as applied to bacterial cultures. J. Bact. 14, 377.

ZoBeLL, C. E. (1932). Factors influencing the reduction of nitrates and nitrites by bacteria in semisolid media. J. Bact. 24, 273.

ZoBell, C. E. \& Feltham, C. B. (1934). A comparison of lead, bismuth, and iron as detectors of hydrogen sulphide produced by bacteria. J. Bact. 28, 169. 